\title{
Menedzsment szakos hallgatók a munkaerőpiacon: az elhelyezkedés mintázatai
}

\author{
M. FÓNAI \\ Debreceni Egyetem Állam-és Jogtudományi Kar, fonai.mihaly@law.unideb.hu
}

\begin{abstract}
Absztrakt. A tanulmány három menedzsment szak végzettjeinek a munkaerő-piaci karrierjét vizsgálja. A gazdaságtudományi és müszaki képzési területhez tartozó szakok (gazdálkodás és menedzsment, müszaki menedzser, humán erőforrás menedzser) az átlagos és több területen jó helyzetû szakokhoz és szakmákhoz tartoznak. A vizsgált szakmák társadalmi rekrutációja középosztálybeli. A munkaerö-piaci sikerességük, így például az elhelyezkedés időtartama, a foglalkoztatás szintje és a jövedelem alapján a kedvező pozíciójú szakmák közé tartoznak. Az egyetemen szerzett szaktudás illeszkedése a végzett munkához magasnak jónak mondható. Elégedettségük a munka különböző összetevőivel hasonlít a többi pályakezdő diplomáséhoz, leginkább a munka tartalmával elégedettek, kevésbé annak presztízsével és az elérhető jövedelemmel. A tanulmányban a Diplomás Pályakövető Rendszer 2011-es és 2012-es adatbázisát elemezzük.
\end{abstract}

Abstract. The present study analyses the labour market career of graduates from three management majors. Majors in connection with the economic and engineering educational field (economy and management, engineering manager, human resources manager) belong to the average and in numerous aspects to the good status majors and professions. The social recrutation of the majors analysed is middleclass. According to their labour market success, such as the duration of finding a job, the level of employment and income they are among professions of favourable position. The knowledge gained at university may be considered well usable in their work. Their satisfaction with the different components of their work is similar to other university graduates, they are most satisfied with the content of their work, and less with its prestige and possible income.In this study we analyse 2011 and 2012 databases of the Graduate Tracking System.

\section{Bevezetés}

Tanulmányunkban három „menedzsment” szak frissdiplomásainak a munkaerő-piaci beilleszkedését, az elhelyezkedés mintázatait vizsgáljuk. Magyarországon a „frissdiplomások” elhelyezkedését a 2000es évektől vizsgálják, több, átfogó kutatás is érintette a felsőoktatás után, a munkaerő-piacra történő bekapcsolódás, az elhelyezkedés jellegzetes mintáit [1]. E vizsgálatok 2010-től az országos Diplomás Pályakövető Rendszer (DPR) keretében folynak, jelen tanulmány is a 2011-2012-es adatfelvétel elemzésén alapul. A munkapiaci elhelyezkedés mintázatait a sikeresség, a szaktudás és végzett munka illeszkedésén, a munkahely és a beosztás jellemzőin, és az elégedettségen keresztül elemezzük. A vizsgált három menedzser szak, illetve szakma jellemzéséhez kitérünk a családi háttér főbb jellemzőire is. 
Elemzésünkbe a gazdálkodás és menedzsment, a humán erőforrás menedzsment, és a műszaki menedzser szakokat, illetve az e szakokon végzetteket vontuk be. A három szak(ma) két képzési területhez tartozik - közöttük kialakulásuk történetét tekintve lényeges különbségek vannak, közös vonásuk, hogy a „vezetés” önálló funkcióként és „szakmaként” való elfogadását követően olyan, új szakmák jöttek létre, melyek a korábbi mérnöki hivatás részfunkcióiból váltak önálló szakmává, így jellemzőik egy része a mérnöki szakmákból következik, míg másik része a vezetéssel összefüggő funkciókból alakult ki [2]. E három szakma összehasonlítására ismereteink szerint még nem került sor, így feltárhatók közöttük érvényesülő hasonlóságok és a különbségek.

\section{Kutatási előzmények}

A hazai kutatási előzmények meghatározó része az országos Diplomás Pályakövető Rendszerhez kapcsolódik - a DPR metodika kialakításához a nemzetközi és a hazai előzményeket és tapasztalatokat egyaránt figyelembe vették.

Ez az alkalmazott mérőeszközökre és azok főbb tartalmi elemeire vonatkozott. Az adatfelvételek egyik célja a munkaerő-piaci sikeresség vizsgálata volt. A „sikeresség” méréséhez objektív és szubjektív mutatókat vettek figyelembe,az objektív mutatók a foglalkoztatással (aktivitás, végzés utáni elhelyezkedés időtartama, beosztás, jövedelem), míg a szubjektív mutatók a szakmai tudás és végzett munka illeszkedésével, a munkahelyváltási szándékkal, valamint a munka összetevőivel való elégedettséggel függtek össze.

A sikert alakító tényezőket (mutatókat) figyelembe véve, Veroszta a sikeresség faktoraiként a sikeres közeget (a fővárosban élő, jobb anyagi családi háttérrel és nyelvtudással rendelkező végzettek), a sikeres karriert a jövedelem és a pozíció alapján (férfiak, budapestiek, jobb családi háttérrel rendelkezők) emeli ki. A stabilitás alapú sikeresség az idősebb korosztályokra, a kistelepüléseken élőkre és a gyereket nevelőkre jellemző, míg a szakmaiság sikerfaktora azokra jellemző, akik egyetemi szintű végzettséggel bírnak, azt megfelelő idő alatt elvégezték, a szakjukat érdeklődés alapján választották, és megfelelő a nyelvtudásuk [5]. A munkaerő-piaci sikeresség fontos mutatója a jövedelem. A kétezres évek elejétől több elemzés foglalkozott a diplomások munkaerő-piaci helyzetével és jövedelmével, ezeket Varga Júlia foglalta össze. A FIDÉV adatfelvételek és a DPR 2010-es adatfelvétele azt mutatta, hogy az átlagos pályakezdő diplomás keresetekhez képest valamennyi képzési területen nőttek a keresetek, leginkább a gazdaságtudományok, az informatika, valamint a jogi és igazgatási területeken, míg a műszaki területen az átlag körüli jövedelmeket regisztráltak. Feltűnő azonban, hogy az ezredfordulóhoz képest a pályakezdő diplomás átlaghoz képest néhány képzési terület pozíciója romlott (agrár, informatika, műszaki), míg más képzési területeken végzettek jövedelme tartósan elmaradt az átlagtól (bölcsészettudomány, természettudomány, orvos-és egészségtudomány, pedagógusképzés) [7]. A kezdő diplomás nettó kereset a DPR 2010-es vizsgálata alapján (a 2007-ben és 2009-ben végzettek körében) 136 ezer forint volt, a gazdaságtudományi képzési területen 159 ezer forint (ez volt a legmagasabb), műszaki területen 145 ezer forint [8] - az általunk vizsgált három szak e két képzési területhez tartozik. A 2011-es adatfelvétel - mely során a 2008-ban és 2010-ben végzetteket keresték meg - néhány képzési területen dinamikusan növekvő kereseteket mutat, így a gazdaságtudományok területén 164 ezer, a műszaki tudományok területén 
176 ezer forintról számoltak be a megkérdezettek, a legmagasabb jövedelmet az informatikusok érték el, 192 ezer forintot kerestek 2010-ben [9]. A sikeresség mérését a végzés utáni elhelyezkedés időtartamával is mérik [10 ]. A Debreceni Egyetem végzettjei folytatott DPR mérés azt mutatta, hogy a társas kapcsolat és a jobb tanulmányi eredmény szignifikáns hatást gyakorolt az elhelyezkedés időtartamára.

A pályakezdők sikeressége mellett az egyik legtöbbet vizsgált kérdés a szakmai végzettség és a konkrét munka illeszkedésének a viszonya. A szerzők leginkább a végzettség felhasználásának szintjét (a megszerzett szakmai tudást milyen mértékben alkalmazzák), valamint a konkrét munkakörhöz szükséges szaktudás képzésbeli szintjét (például közép, vagy felsőfokú végzettség szükséges-e az adott pozíció ellátásához) vizsgálják. Györgyi Zoltán a szaknak a munkahelyhez jutásban játszott szerepe és a szak, valamint a munka kapcsolata alapján a képzési területek négy munkaerő-piaci szektorát különböztette meg [11]. Ezek: a kedvező elhelyezkedést biztosító képzési területek (orvos-és egészségtudományi, jogi és igazgatási), átlagos területek (gazdaságtudományi, műszaki, informatikai), vegyes szektor, azaz nehéz és könnyű elhelyezkedés egyaránt (pedagógusképzés), kedvezőtlen munkaerő-piaci területek (agrár, bölcsészettudományi, társadalomtudományi, természettudományi) [GYÖRGY Z. 42]. Látható, hogy ebben a modellben az általunk vizsgált szakok pozíciója átlagos. Más metodikával, ám hasonló következtetésekre jut Varga Júlia a 2011-es adatfelvétel eredményei alapján, ugyanakkor a szerző elemzései arra is rámutatnak, hogy egy-egy képzési terület pozíciói például az illeszkedést illetően rövidtávon is hullámzóak, inkább arról lehet szó, hogy csak a hosszabb távú trendek igazolják Györgyi modelljét [12]. A Debreceni Egyetem DPR vizsgálata keretében a foglalkoztatás minőségét az alul, illetve túlképzettek arányával is jellemezte, ezek az eredmények a képzési területeket illetően hasonlók Györgyi és Varga megállapításaihoz, így például a túlképzettek aránya a kedvezőtlen munkaerő-piaci területeken magasabb [13].

Tanulmányunkban foglalkozunk a munkaerő-piaci beilleszkedés egy fontos elemével, a munka különböző összetevőivel való elégedettséggel is. Ennek elméleti hátterével és kutatási előzményeivel leginkább Kiss Paszkál foglalkozott, összefoglalva a témára vonatkozó nemzetközi szakirodalom főbb megállapításait és modelljeit is. [14]. A munkával való elégedettséget makroszintű hatások (értékek, vonatkozási csoportok, GDP, globális folyamatok), szervezeti tényezők (szervezeti kultúra, munkastressz, életpálya, aktuális szervezeti szerep) és a személyes jellemzők alakítják (A-típusú viselkedés, kontrollhely, motiváció) [15]. A DPR mérések azt mutatják, hogy a frissdiplomások a munka személyi és tárgyi körülményeivel, és a munka tartalmi részével inkább elégedettek, mint a szakmai presztízzsel, jövedelemmel és a karrierépítés lehetőségeivel [16].

\section{Módszer és minta}

Adatbázisunk a Diplomás Pályakövető Rendszernek a 2011-es és 2012-es, a végzettek körében folytatott vizsgálata, melynek keretében 45323 frissdiplomás válaszolt az on-line kérdőíves megkeresésre (ez akkor a megkeresett végzettek 19,05 százaléka volt). [17]. A DPR kutatásokhoz a felsőoktatási intézmények által a végzett hallgatóiknak kiküldött on-line önkitöltős kérdőivet használtak. A teljes mintából a gazdálkodás és menedzsment, a humán erőforrás menedzsment, és a műszaki menedzser szakokat, illetve az e szakokon végzetteket vontuk be elemzésünkbe, 1099, 517, 
illetve 215 főt. A nők aránya jelentősen eltér az egyes szakok, szakmák esetében, a gazdálkodás és menedzsment területén 67,8 százalék, a műszaki menedzserek körében 41 százalék, és a legmagasabb a HE menedzserek esetében 84,4 százalék.

\section{Eredmények}

\subsection{A végzett menedzser szakos hallgatók családi háttere}

A felsőoktatási expanzió korszakában csökkent a társadalmi egyenlőtlenségek mértéke a továbbtanulásban, és részben a munkaerő-piaci előrejutásban. Ez azonban nem jelenti azt, hogy maguk az egyenlőtlenségek teljesen eltűntek volna. Ha csak a közelmúlt magyar felsőoktatási kutatásaira tekintünk, azok a származási egyenlőtlenségeknek a képzési területekkel, szakokkal és karokkal összefüggő hatását hangsúlyozzák [18]. A DPR vizsgálatok eredményei is markáns különbségeket mutatnak a képzési területek és a hozzájuk tartozó szakok között (az orvos-és egészségtudományi képzési területen belül is komoly különbségek érvényesülnek, ez a teljes képzési területen elmosódik), a jogi és igazgatási területen 56 százaléka diplomás, ezzel szemben a pedagógusképzésben 28 százaléka (minél magasabb egy képzési területen a diplomás szülők aránya, annál magasabb lesz közöttük az egyetemi végzettségűeké). A gazdaságtudományi területen 51 , a műszaki területen 43 százalék volt 2010-ben a diplomás szülők aránya a frissdiplomások esetében [19]. Milyen különbségek vannak a három menedzser szak frissdiplomásai között az apák iskolai végzettsége alapján (1. ábra).

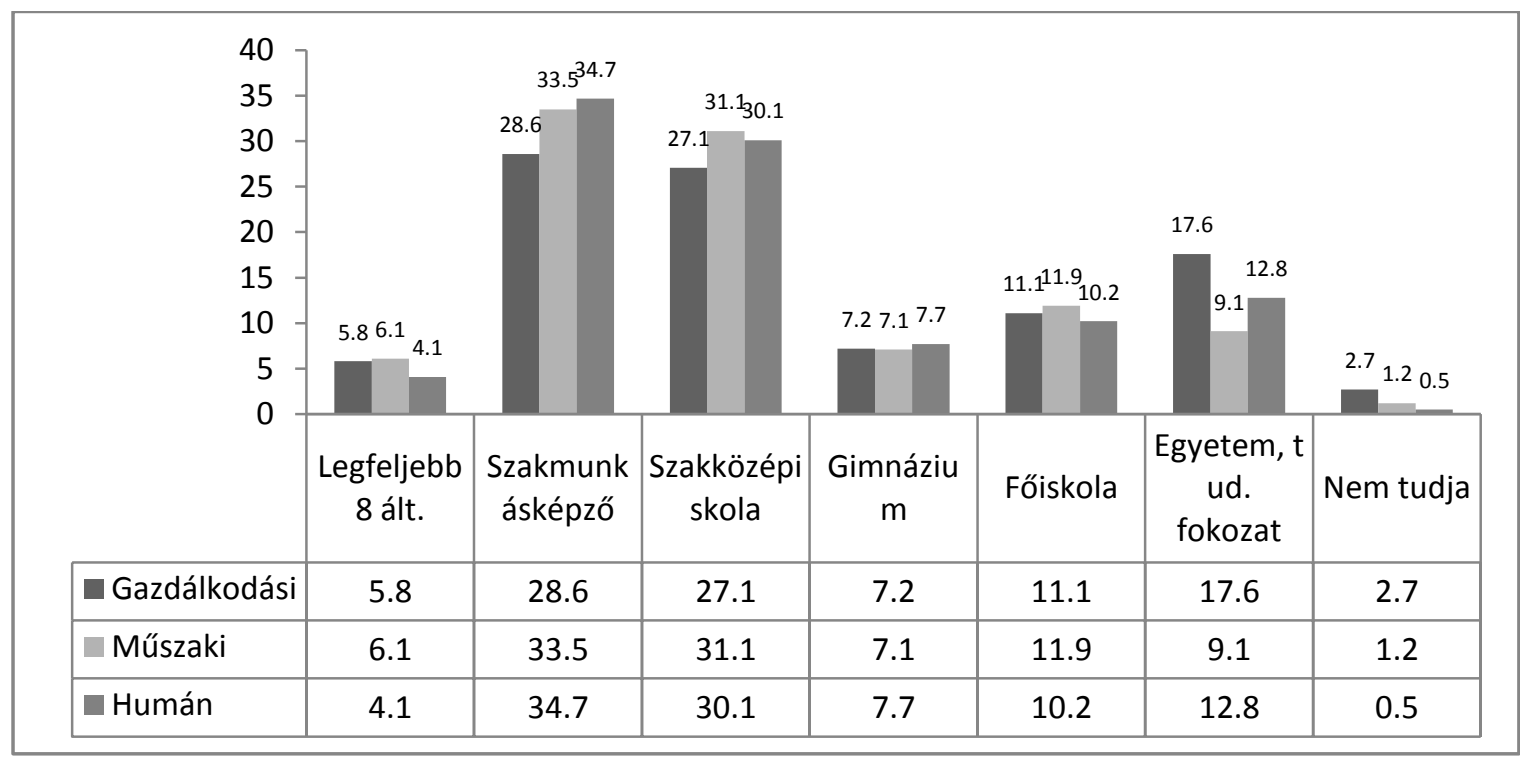

1. ábra: Az apák iskolai végzettsége, százalékban

(Forrás: DPR 2011-2012. adatbázis. sign.: ,002)

Az apák iskolai végzettsége között szignifikáns különbség érvényesül. A diplomás apák aránya a gazdálkodás menedzsment szakosok esetében a legmagasabb, a műszaki és humán erőforrás menedzserek között kisebb a különbség. A „gazdálkodás és menedzsment” szakot (és szakmát) a 
közgondolkodás „közgazdászként” azonosítja, magasabb presztízst tulajdonítva neki, mint a műszaki menedzsereknek, vagy a viszonylag kevésbé ismert humán erőforrás menedzsereknek. Úgy tűnik, az adatfelvétel idején még működött az a mechanizmus, mely a társadalmi státusz kijelölésénél az apák iskolai végzettségét preferálja - az anyák iskolai végzettsége között is szignifikáns különbséget találtunk, az ő iskolai végzettségük ekkor még alacsonyabb volt az apákénál. Néhány szakma esetében tradicionálisan „továbbörökítődik” a foglalkozás a leszármazottak körében, kérdés, esetünkben érvényesül-e ez a jelenség (2. ábra).

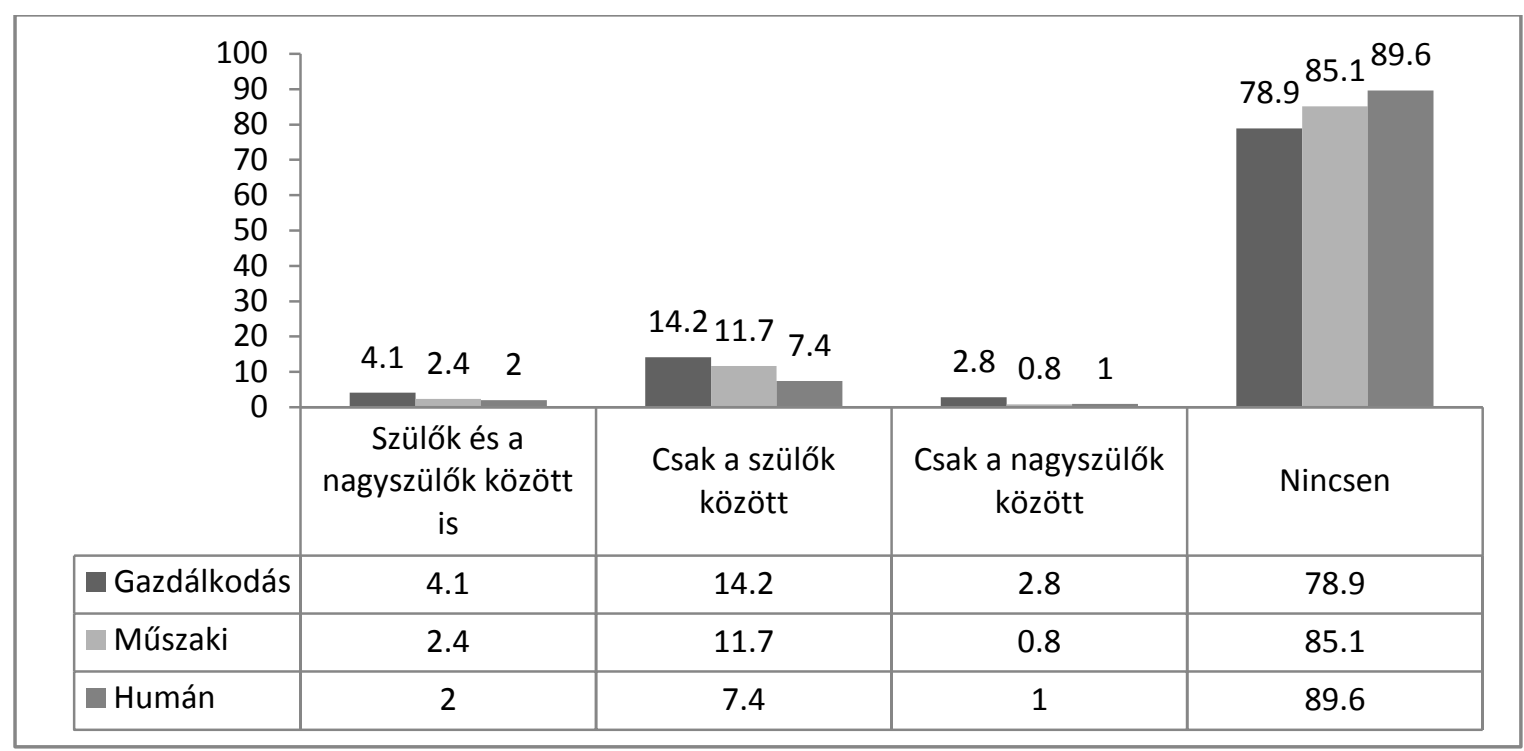

2. ábra: Van-e a családban hasonló szakterületen végzett és dolgozó családtag, százalékban

(Forrás: DPR 2011-2012. adatbázis. sign.: ,001)

A három menedzser szakma között ebben az esetben is szignifikáns különbség van. Úgy tűnik, a „továbbörökítés”, a jó értelemben vett „dinasztikusság” részben a szak(ma) státuszával, részben a múltjával, ismertségével van összefüggésben, azaz inkább beszélhetünk arról, hogy a közgazdászok „dinasztikusabban” viselkednek, mint a műszaki mérnökök, vagy a viszonylag új szakmának számító humán erőforrás menedzserek. A szülők társadalmi státuszával és a részben azzal is összefüggő presztízsével, illetve a választott szak presztízsével magyaráztuk a „dinasztikusság” jelenségét a Debreceni Egyetem Tehetséggondozó Programjába (DETEP) került hallgatók esetében is, azaz hasonló végzettségű családtagok nagyobb arányát akkor tapasztalhatjuk, ha a szakma magas státuszú, illetve jelentős társadalomtörténeti múltja és hagyománya van [20].

\subsection{Az állásba kerülés módozatai}

Egy állás betöltésének számos, formális vagy informális módja van, a pályázati úttól a személyes kapcsolatokig. Saját kutatásaink és más kutatásoknak az eredményei azt mutatják, hogy a kilencvenes, kétezres években a formális és informális módoknak, csatornáknak körülbelül egyforma szerepe volt abban, hogy valaki állásba kerüljön, ám relatíve a legnagyobb szerepet a személyes kapcsolatoknak tulajdonították a különféle kutatásokban erről megkérdezett frissdiplomások [21]. 
Az állás betöltésének módját jelentős mértékben alakítja az érintettek lehetséges és tényleges munkaés pályaválasztási stratégiája, melyet több tényező is befolyásol. E tényezők között az intenzív munkatapasztalat, a külföldi és hazai mobilitás, a továbbtanulás, a családi háttértámogatás, a tanulás melletti „bedolgozás”, a külföldi aspirációk, és a hagyományos „pályára állás” mutatható ki [22]. A különböző tényezők eltérő módozatokat indukálhatnak egy konkrét állás betöltésénél. Mintánkban ez a következő módon alakult (3. ábra)

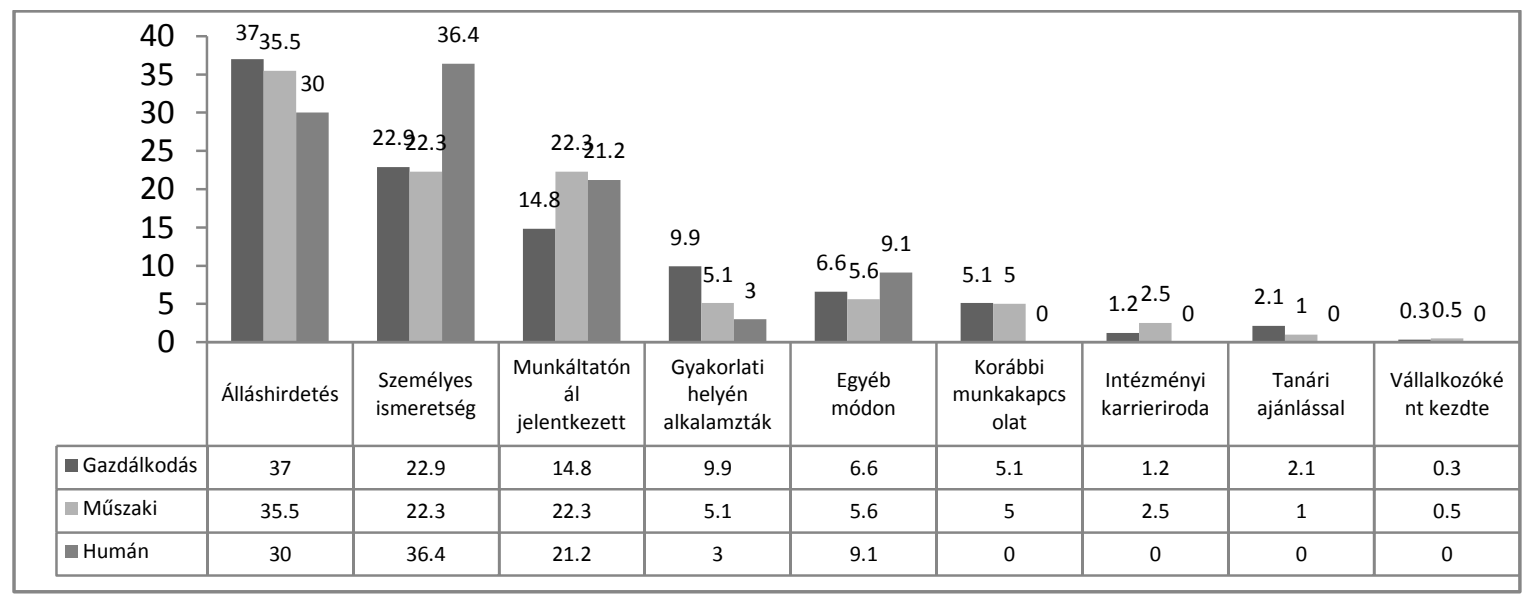

3. ábra: Hogyan jutott az abszolutórium utáni első munkájához, százalékban

(Forrás: DPR 2011-2012. adatbázis. sign.: ,332)

A három vizsgált szakma esetében a formális út választása a meghatározóbb, az álláshirdetésre jelentkezés, önéletrajz beadása a munkáltatóhoz, gyakorlati helyen alkalmazták, korábbi munkakapcsolat. Meglepően alacsony a felsőoktatási intézmények karrierirodájának a szerepe a munkaerő-piaci karrierben, akárcsak a tanároké - ez az egyetemek működésének az átgondolását veti fel, hisz a DPR kutatás alapján még 2012-ben is igen alacsony intenzitásúak voltak az intézmények munkaerő-piaci kapcsolatai.

Jellegzetes eltérések tapasztalhatók a három szakma képviselői között az álláskeresési módokat, stratégiákat illetően. Álláshirdetéssel leginkább a gazdálkodás és menedzsment szakon végzettek, személyes ismeretséggel leginkább a HE menedzserek, önéletrajz beadásával a műszaki menedzserek kerültek állásba, ez utóbbi csoport az, amelyik esetében a gyakorlati hely és a korábbi munkakapcsolat is jelentős szerepet kap. Úgy tűnik, a gazdálkodás és menedzsment szakosok helyezkednek el leginkább pályázati - formális módon, nagyobb szerepet kap ezek mellett a gyakorlati képzésből eredő kapcsolatok szerepe a múszaki menedzsereknél, és relatíve a legmeghatározóbb az informális út a HE menedzserek esetében. Ez magyarázható a munkaerő-piaci kínálattal, a potenciális foglalkoztatók méretével és tulajdonosi szerkezetével is.

\subsection{A munkaerő-piaci sikeresség néhány eleme}

A munkaerő-piaci sikeresség elemei közül az egyik fontos mutató, hogy a végzettek az abszolutórium megszerzése után mennyi idő alatt tudnak elhelyezkedni. Ezen túlmenően vizsgáljuk a munkaerő-piaci 
részvételt, a beosztást, és a jövedelmet. Az átlagos idő, amely az első munkahely megtalálásáig eltelt, 2007 és 2010 között a képzési szinttől is függően 3,3 - 3,6 hónap volt [23]. Ez lényegesen különbözött az egyes képzési területek között, leggyorsabban az informatikusok, leghosszabb idő alatt a pedagógusképzésben végzettek tudtak elhelyezkedni. Lássuk, hogy az egyes menedzser szakokon végzettek között hogyan alakult ez az időtartam (4. ábra).

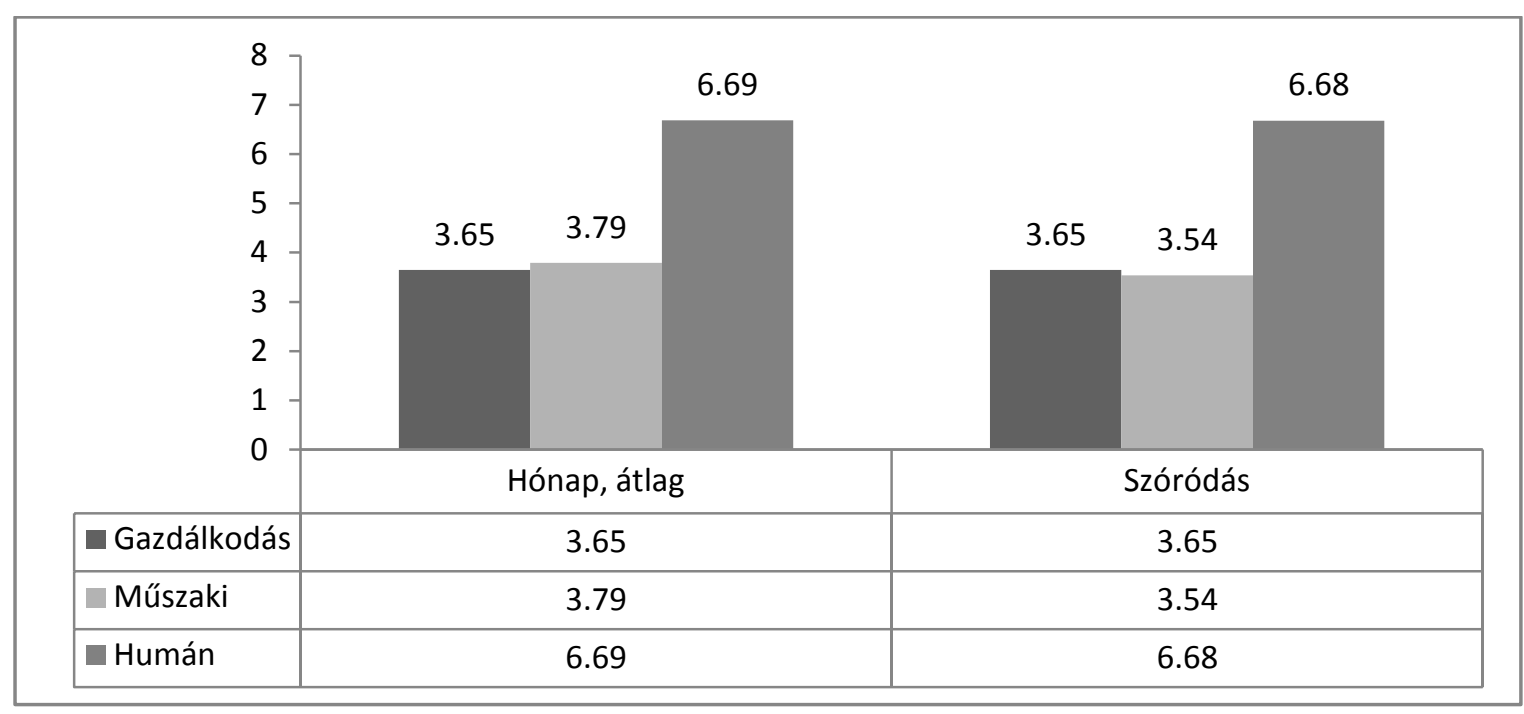

4. ábra: Abszolutórium után összesen hány hónapig kereste első munkáját

(Forrás: DPR 2011-2012. adatbázis. sign.: ,000 (gazdálkodás és menedzsment $N=321$, müszaki menedzser $N=203$, HE menedzser $=57)$ )

A gazdálkodási menedzsment szakon végzettek a diplomás átlaghoz közel, és a saját képzési területük többéves átlagának megfelelő idő alatt tudott elhelyezkedni, akárcsak a műszaki menedzserek, akik a saját területükön kialakult átlagos időnél valamivel hamarabb jutottak álláshoz. Ezzel szemben sokkal hosszabb időt vett igénybe a humán erőforrás menedzserek elhelyezkedése (az alacsony válaszadói elemszám miatt azonban ezzel az értékkel óvatosan kell bánni). Valószínű, hogy a szakma viszonylagos újdonsága, és a munkaerőpiac struktúrája is hozzájárul ehhez, hisz a tapasztalatok szerint leginkább a külföldi tulajdonú (multinacionális) cégek alkalmaznak jelentős számban HE menedzsereket, a magyar tulajdonú nagyvállalatok és KKV szektor kevésbé. Ez a jelenség mindenképpen további elemzést érdemel. Ugyanakkor a munkanélküli helyzet előfordulását illetően már kedvezőbb a HE menedzserek helyzete, a gazdálkodás és menedzsment területen végzettek átlagához közeli a munkanélküliségi időszakok előfordulása a körükben (volt munkanélküli? gazdálkodás és menedzsment 28,2\%, műszaki menedzserek 36\%, HE menedzserek 30,8\%), azaz a munkanélküliség esélye leginkább a múszaki menedzserek körében fordult elő. A kérdezéskori munkaerő-piaci státusz az egyes szakmákban a következő volt (5. ábra). 


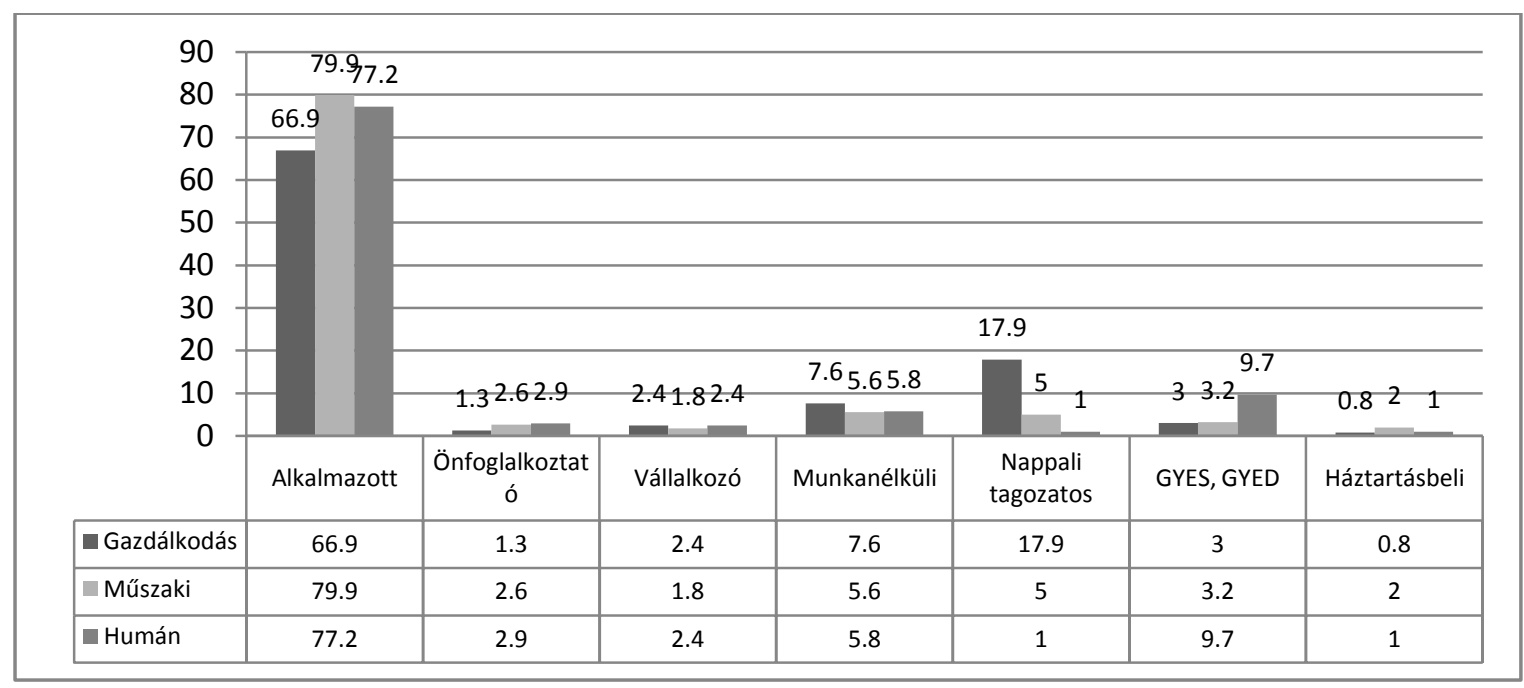

5. ábra: A megkérdezettek munkaerő-piaci státusza, százalékban

(Forrás: DPR 2011-2012. adatbázis. sign.: ,000)

A HE menedzserek, ha már állásba kerültek, leginkább a műszaki menedzserekhez hasonló foglalkoztatási jellemzőkkel bírnak, de a nappali tagozatos hallgatói státusztól eltekintve a gazdálkodás és menedzsment szakon végzettekéhez is hasonló a státuszuk. Ez utóbbi csoport esetében a BSc-én végzettek közül jelentős számban tanultak tovább a mester szinten, a másik két szakmánál ez kevésbé jellemző. Ami szembetűnő, az a vállalkozók és önfoglalkoztatók alacsony aránya. Ha a „munkaerő-piaci részvétel” kérdésére adott válaszokat vesszük figyelembe, akkor azt látjuk, hogy a gazdálkodás szakosok 78 százaléka, a műszaki menedzserek 87,4 százaléka, és a HE menedzserek 88,6 százaléka jelenleg is dolgozik, azaz foglalkoztatott - ez megfelel a képzésterületi DPR eredményeknek (a gazdálkodás és menedzsment esetében a foglalkoztatást a nappali tagozatos tanulók aránya is alakítja). Mindez azt jelenti, hogy azok esetében is kedvezők a foglalkoztatási mutatók, akik egyébként nehezebben jutottak munkához.

A munkaerő-piaci sikeresség mutatója, hogy betölt-e valaki vezető pozíciót. Eltekintve a foglalkoztatottak létszámától, a válaszolók megoszlása e vonatkozásban a következő (6. ábra).

\begin{tabular}{|c|c|c|c|c|c|}
\hline \multirow[t]{2}{*}{$\begin{array}{r}60 \\
50 \\
40 \\
30 \\
20 \\
10 \\
0\end{array}$} & 1.92 .71 .9 & $13.6^{17.9_{15.7}}$ & $6.5^{12.2} 8.8$ & 55.74649 .1 & $22.421 .1^{24.5}$ \\
\hline & Felső vezető & Középvezető & Alsó vezető & $\begin{array}{l}\text { Beosztott } \\
\text { diplomás }\end{array}$ & $\begin{array}{l}\text { Beosztott nem } \\
\text { diplomás }\end{array}$ \\
\hline - Gazdálkodás & 1.9 & 13.6 & 6.5 & 55.7 & 22.4 \\
\hline Múszaki & 2.7 & 17.9 & 12.2 & 46 & 21.1 \\
\hline Humán & 1.9 & 15.7 & 8.8 & 49.1 & 24.5 \\
\hline
\end{tabular}

6. ábra: Milyen beosztásban dolgozik, százalékban

(Forrás: DPR 2011-2012. adatbázis. sign.: ,017) 
A menedzser szakokon végzettek mintegy fele beosztott diplomás, élethelyzetükből eredően a felső és középvezetők aránya viszonylag alacsony, bár a középvezetőké már jelentősnek mondható. A műszaki menedzserek azok, akik leginkább betöltenek valamilyen szintű vezetői pozíciót, esetükben látszik legtipikusabbnak a „menedzseri” életút és karrier, a jellemzően inkább beosztottak a gazdálkodás szakon végzettek. A válaszolók jelentős része nem diplomás munkakörben dolgozik, ami az „illeszkedés” kérdésével is összefügg - a műszaki menedzserek körében alacsonyabb az alulfoglalkoztatottak aránya, és a HE menedzsereknél magasabb.

A pályakezdő keresetek is mutatják egy-egy szakma munkapiaci sikerességét. A DPR adatfelvételek azt mutatják, hogy a havi nettó keresetekben jelentős hullámzás tapasztalható, ami nem szükségszerűen az adott területen elérhető jövedelmek hektikus mozgásából fakad, valószínű, hogy a válaszadók összetétele és a jövedelemre vonatkozó válaszok megbízhatósága magyarázza a tendenciátlan ingadozást [24]. A három vizsgált menedzser szakma a kedvezőbb kereseti pozíciójú képzési területek közé tartozik, hisz a 2010-es DPR kutatás a válaszadók körében 136 ezer forint átlagos keresetet detektált, a gazdaságtudományi képzési területen 164 ezer, a múszakin pedig 145 ezer forintot; ezzel a gazdaságtudományi szakokon végzettek akkor a legjobban fizetettek voltak, míg a műszaki területen végzettek a 4. helyen álltak [25]. A 2011-2012-es lekérdezéskor a diplomás nettó átlagkereset 170 ezer forint volt, a gazdaságtudományi képzési területen 190 ezer, a műszakin pedig 207 ezer forint, ezzel a műszakisok az informatikusok után a második helyen voltak a képzési területek közül, míg a gazdaságtudományi szakokon végzettek a harmadik helyen [26], azaz e képzési területek a legjobban fizetők voltak. Lássuk, hogy a vizsgált szakmák esetében hogyan alakultak a jövedelmek (7. ábra).

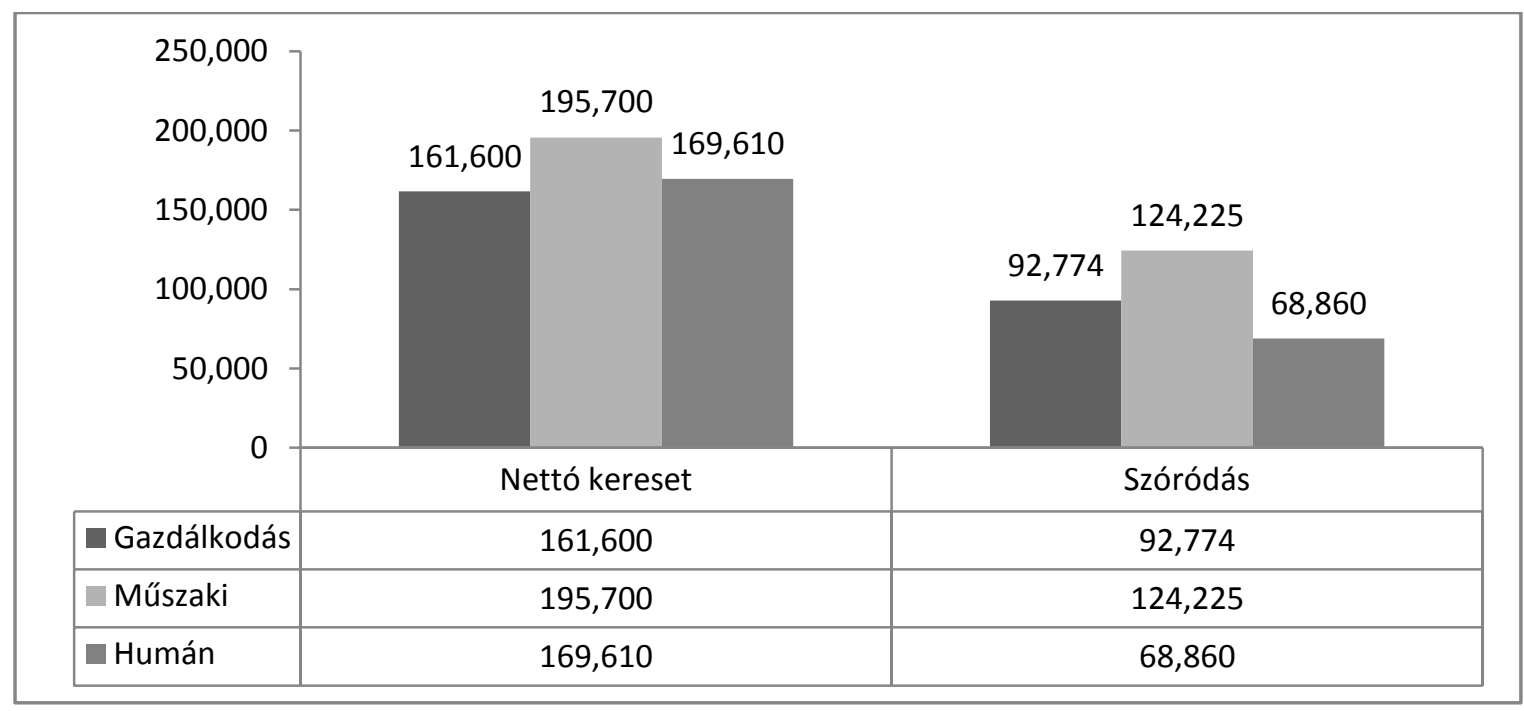

7. ábra: Havi nettó kereset, forintban

(Forrás: DPR 2011-2012. adatbázis. sign.: ,000 (gazdálkodás és menedzsment $N=658$, müszaki menedzser $N=$ 360, HE menedzser $=140$ ))

A havi nettó jövedelmek sorrendje megfelel a képzésterületi sorrendnek, a múszaki menedzserek kiugró fizetésével. Viszonylag meglepő a gazdálkodási menedzsment szakon végzettek szerényebb javadalmazása, a két másik szakmához és a saját képzési terület átlagához képest is. Úgy tűnik, a 
műszaki képzési területhez tartozó szakok, szakmák esetében kisebb a keresetek közötti különbség, mint a gazdaságtudományi területen, hisz a vizsgált két szak(ma) 20-30 ezer forinttal marad el a saját képzési terület átlagától; a HE menedzserek a vizsgálat időpontjában a végzett diplomások átlagának megfelelő jövedelemmel rendelkeztek, míg a gazdálkodás szakon végzettek esetében az eltérés mintegy nyolcezer forint.

A munkaerő-piaci sikeresség néhány területe alapján a három vizsgált menedzser szakmáról vegyes képet tudunk rajzolni, hisz az egyes „sikerességi” területek között nincs kongruens megfelelés, hatásuk kiegyenlíti egymást, így a gyorsabb elhelyezkedés nem jár együtt magasabb keresettel, és a hosszabb időtartamú elhelyezkedés nem zárja ki a biztos állást, a vezető pozíciók betöltését, és a jövedelmet [27].

\subsection{A megszerzett tudás és a végzett munka illeszkedése}

A megszerzett tudás és a végzett munka illeszkedése több szempontból is fontos, így jelzi a munkaerőpiaci sikerességet, alakítja az érintettek elégedettségét a munkájukkal, jelzi a képzés hiányosságait és strukturális egyenlőtlenségeit [28]. A végzettség szakterületével illeszkedő foglalkozásban dolgozók aránya a gazdaságtudományi képzési területen valamivel magasabb volt (81,3, illetve 79,3 százalék), mint a diplomás átlag, mely a 2008-ban végzetteknél 80,5 százalék, a 2010-ben végzetteknél pedig 77,3 százalék. Ugyanez a mutató a műszaki területen lényegesen magasabb volt, mindkét évben 85,2 százalék. Hasonló a helyzet a végzettség szintje esetében is, ami azt jelenti, hogy az illeszkedést jelentős mértékben az alakítja, hogy valaki a végzettségének megfelelő szintű munkát végez [29]. Vizsgáljuk meg, hogyan alakul az illeszkedés a három szakma esetében (8., 9. és 10. ábra).

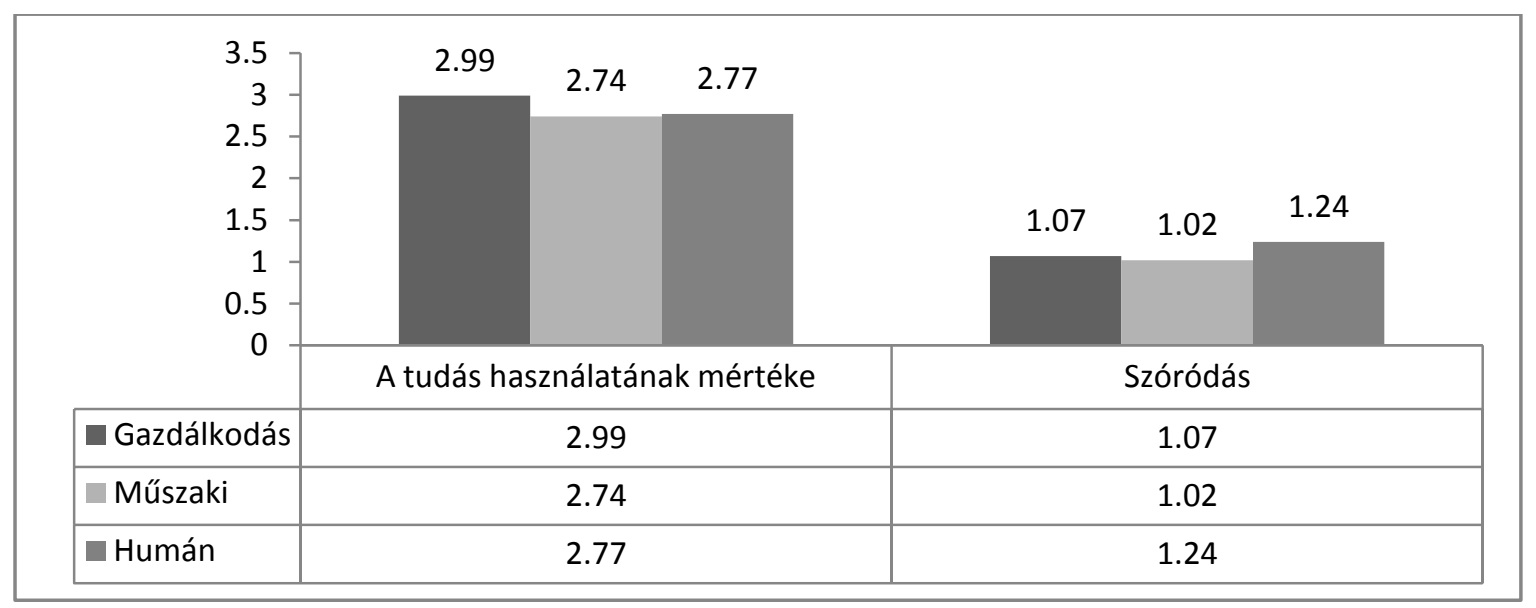

8. ábra: Milyen mértékben használja a tanulmányai során elsajátított tudást (ötfokozatú skálán)

(Forrás: DPR 2011-2012. adatbázis. sign.: ,000 (gazdálkodás és menedzsment $N=797$, müszaki menedzser $N=423$, HE menedzser $=173$ )

A végzés után 1-3 évvel a pályakezdő menedzserek úgy érzik, a szakmai tudásukat szerény mértékben tudják használni a munkájukban. Ennek egyik fontos következménye, hogy magával a munkával való elégedettségük is szerény lesz - ez azonban általános jelenség a frissdiplomások körében [30], a munkában eltöltött idővel is összefügghet. leginkább a gazdálkodás és menedzsment szakon végzettek 
használják a megszerzett tudásukat, a másik két szakma között e tekintetben nincs különbség. Jól magyarázza a jelenséget az is, hogy milyen szakterületen szerzett tanulmányokat alkalmaznak a frissdiplomások a munkájuk során (9. ábra); látható, hogy a gazdálkodás és menedzsment szakosok körében magas a saját és kapcsolódó tanulmányok szerepe a munkában. Meglepő, hogy a HE menedzserek esetében milyen magas a más területen szerzett tudás alkalmazásának a mértéke - ez arra utal, hogy esetükben a képzési spektrum az, ami eleve „széles” tudást ad, amit használni tudnak, ezt támasztja alá, mivel más végzettség kis mértékben fordul elő a körükben. A műszaki menedzserek is jelentősnek tartják azt a szakmai tudást, amely más szakterülethez kapcsolódik.

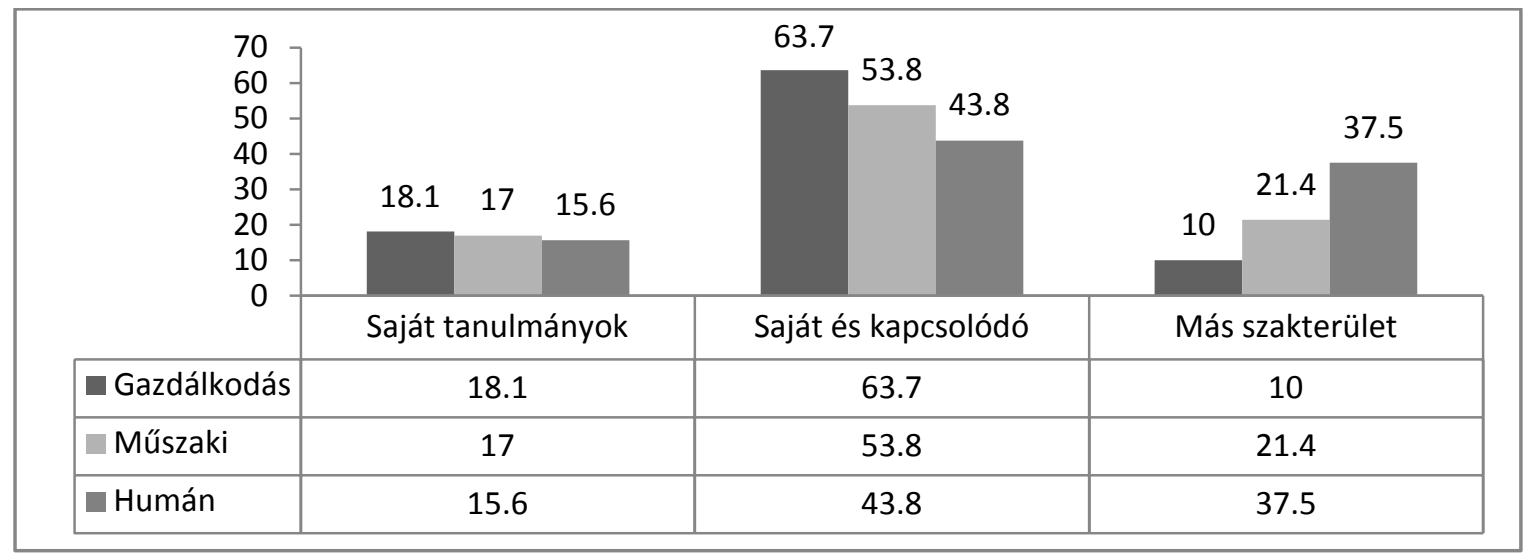

9. ábra: Milyen szakterületen végzett tanulmányok felelnek meg legjobban a munkájának, százalékban

(Forrás: DPR 2011-2012. adatbázis. sign.: ,000)

A két, vizsgált jelenség között szoros kapcsolat van, hisz az elsajátított tudás használatának alacsony szintje azzal is összefügg, hogy ténylegesen milyen szakterületen végzett tanulmányok felelnek meg a konkrét munkának. Ezekből is következik, hogy milyen szintű képzettség felel meg a ténylegesen folytatott munkának, illetve, a munkához szükséges képzettség szintje is alakítja azt, hogy mennyire tudják használni a szaktudásukat (10. ábra). Az ábra azt mutatja, hogy a szaktudás - végzett munka inkongruenciáját jelentős mértékben alakítja az, hogy a munka maga nem igényel felsőfokú végzettséget.

\begin{tabular}{|c|c|c|c|c|c|c|}
\hline $\begin{array}{l}70 \\
60 \\
50 \\
40 \\
30 \\
20 \\
10\end{array}$ & $\begin{array}{ll}0 & 0.5\end{array}$ & 0 & $\begin{array}{lll}1.2 & 2.1 & 2.3\end{array}$ & \multicolumn{2}{|l|}{$\begin{array}{r}14.114 .8 \\
\end{array}$} & $21.2^{24.5^{32}}$ \\
\hline & $\mathrm{PhD}$ & & $\begin{array}{c}\text { Egyéb } \\
\text { posztgraduális }\end{array}$ & Egyetem, MA, MSc & Főiskola, BA, BSc & $\begin{array}{l}\text { Nem igényel } \\
\text { felsőfokút }\end{array}$ \\
\hline - Gazdálkodás & 0 & & 1.2 & 14.1 & 62.8 & 21.2 \\
\hline Múszaki & 0.5 & & 2.1 & 14.8 & 58.1 & 24.5 \\
\hline Humán & 0 & & 2.3 & 5.8 & 59.9 & 32 \\
\hline
\end{tabular}

10. ábra: Milyen szintű képzettség felel meg jelenlegi munkájának, százalékban

(Forrás: DPR 2011-2012. adatbázis. sign.: ,003) 


\subsection{Elégedettség a munkával}

A munkával, a munka különböző összetevőivel való elégedettségre vonatkozó kutatási eredmények azt mutatják, hogy a frissdiplomások a munka személyi körülményeivel és szakmai, tartalmi részével elégedettek, miközben a szakmai presztízzsel, előmenetellel és jövedelemmel kevésbé [31]. Ennek oka a pályakezdés és a „kapunyitási pánik” lehet. Láttuk, hogy a szaktudás használatáról is kritikusan nyilatkoznak, ez teljesen egybecseng a munka különböző területeivel való elégedettséggel is. Pályájuk kezdetén még alig érzékelik a szakmájuk presztízsét, és elégedetlenek az elérhető jövedelmekkel is. Az általunk vizsgált szakmák esetében is hasonló a helyzet, csekély az eltérés az országos eredményekhez képest (11. ábra).

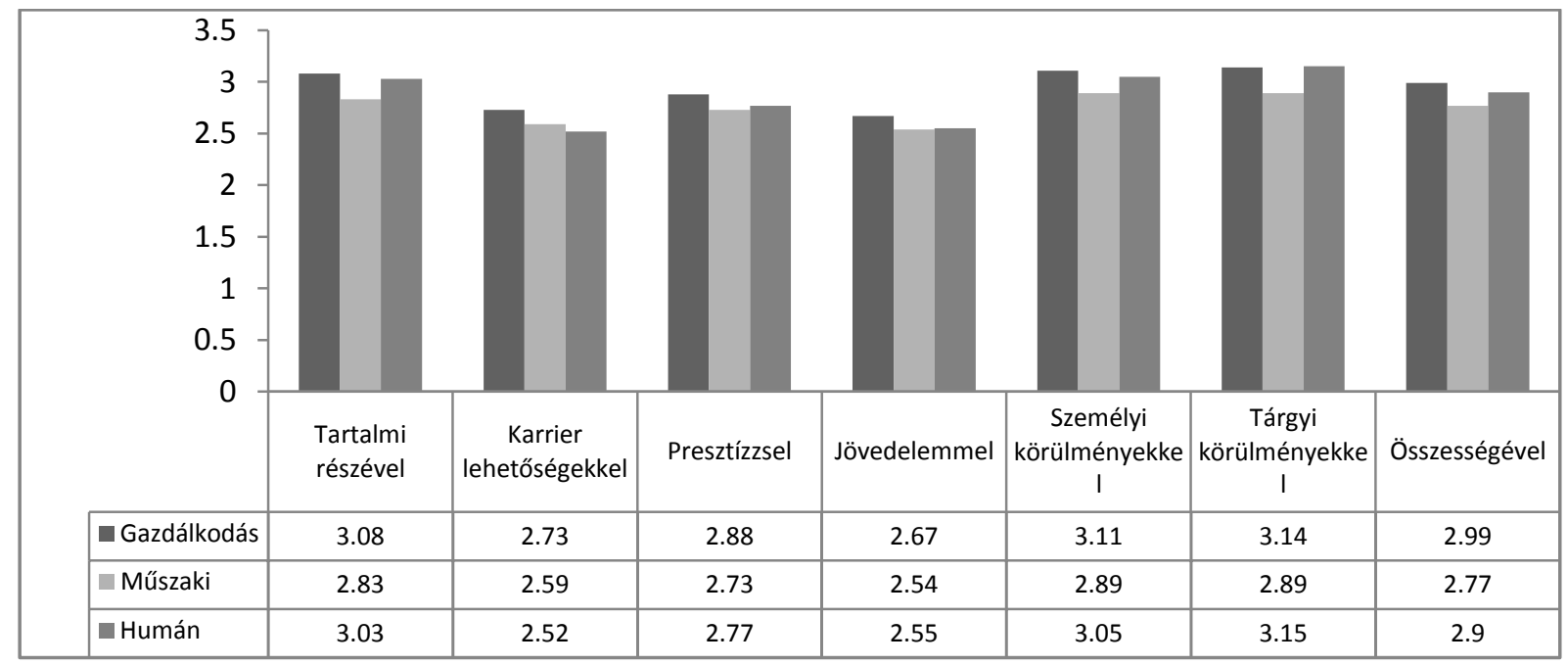

11. ábra: mennyire elégedett...(ötfokozatú skála)

(Forrás: DPR 2011-2012. adatbázis)

A három menedzser szakma közül a gazdálkodás és menedzsment szakon végzettek a legelégedettebbek, ám ez relatív, hisz összességében is alacsony az az érték, melyet választottak. Legkritikusabbak a műszaki menedzserek, válaszaik jelentős elégedetlenséget mutatnak. A munkával, annak összetevőivel való elégedettség sok szempontból nehezen magyarázható, hisz például a vizsgált szakám frissdiplomásai jóval a megkérdezett diplomások átlaga felett keres. Az elégedetlenséget, a szaktudás alkalmazására vonatkozó válaszok alapján abban ragadhatjuk meg, hogy a frissdiplomások úgy érzik, tudásukat csak részben tudják alkalmazni. Bár a munkatartalmi részével viszonylag elégedettek, úgy tűnik, a pályakezdők magas elvárás szintje épp e területen teszi inkongruenssé saját helyzetük értékelését, amihez hozzájárul az észlelt alacsony presztízs és karrier lehetőség is.

\section{Összegzés}

Tanulmányunkban három menedzser szak frissdiplomásainak az elhelyezkedési mintázatait vizsgáltuk. A három szak, illetve szakma az átlagos, sok szempontból kedvező helyzetű képzési területekhez tartozik, ez mindenképpen hat a vizsgált munkaerő-piaci folyamatokra is. Bár a szakmák 
egyetemen belüli és társadalmi pozíciója, illetve státusza kedvezőnek mondható, társadalmi rekrutációjuk a középosztályi, alsó-középosztályi családokból történik.

A végzés után a terület frissdiplomásai inkább az elhelyezkedés formális módozatai alapján találnak állást. Munkaerő-piaci sikerességük jellemzője, hogy a kedvezőtlen jelenségek, például az elhelyezkedés időtartama, kiegyenlítődik például az állás biztonságával, a foglalkoztatás mértékével, valamint a többi frissdiplomás csoporthoz képest magasabb jövedelemmel. A megszerzett szaktudásuk és a végzett munka között viszonylag jelentős inkongruencia tapasztalható, amit elsősorban az ellátott tevékenységekhez szükséges végzettségi szint magyaráz, a munkájukhoz egynegyedük esetében nincs szükség felsőfokú végzettségre. Ezek a jelenségek is magyarázzák a munkával és a munka összetevőivel való elégedettségüket; leginkább mégis a munka tartalmával, valamint annak személyi és tárgyi körülményeivel elégedettek, és kevésbé a munka presztízsével, a karrier lehetőségekkel, és a jövedelmekkel - ez utóbbi ellentmondásos, hisz ezeken a területeken a diplomás átlaghoz képest magas kezdő fizetések vannak. A tapasztalt inkongruenciák a pályakezdők élethelyzetéből, a „kapunyitási pánikból”, és a más diplomás szakmákhoz, valamint a már régebb óta dolgozó diplomások helyzetével való összevetésből fakadhat.

\section{Hivatkozások}

[1] Zs. Veroszta (2010), A munkaerö-piaci sikeresség dimenziói frissdiplomások körében, In: Garai O. - Horváth T. - Kiss L. - Szép L. - Veroszta Zs. (szerk.): Frissdiplomások 2010. Educatio Társadalmi Szolgáltató Nonprofit. Kft., Budapest, 11-36., 30-31.

[2] J. Németh (1999), A technika és mérnökség magyarországi története, Mủegyetemi Kiadó, Budapest

[3] Gy. Bakacsi (2003), Szervezeti magatartás és vezetés, Budapest, KJK - Kerszöv.

[4] M. Dobák (2002), Szervezeti formák és vezetés, KJK - Kerszöv, Budapest

[5] S. Klein (2005), Vezetés-és szervezetpszichológia, Budapest, Edge 2000. Kft .

[6] L. Hajós, Cs. Berde (szerk.) (2007), Emberi erőforrás gazdálkodás, AMTC AVG, Debrecen

[7] Diplomás pályakövetés - Kézikönyv címmel (szerkesztette) (2009): Horváth Tamás, Kiss László, Nyerges Andrea és Roberts Éva). Educatio Társadalmi Szolgáltató Nonprofit Kft. Budapest

[8] I. J. Tóth, Z. Várhalmi (2008), Diplomás pályakezdők a versenyszektorban, In: Diplomás pályakövetés 1. - Hazai és nemzetközi tendenciák. Educatio Társadalmi Szolgáltató Kht. Országos Felsőoktatási Információs Központ, Budapest, (Szerk.: fábri István-Horváth Tamás-Kiss László-Nyerges Andrea) 99-118. p.

[9] J. Varga (2010), A pályakezdő diplomások keresete, munkaerő-piaci sikeressége a 2000-es évek elején, In: Garai O. - Horváth T. - Kiss L. - Szép L. - Veroszta Zs. (szerk.): Frissdiplomások 2010. Educatio Társadalmi Szolgáltató Nonprofit. Kft., Budapest, p. 5981., 61., 64., 143-171. 
[10] M. Fónai, Á. Kotsis, E. Szűcs (2014), A munkaerô-piaci sikeresség vizsgálata a Debreceni Egyetem végzettjeinek utókövetésén keresztül, Felsőoktatási Műhely, 4. p. 91-107., 102-104.

[11] Z. Györgyi (2010), Munkaerő-piaci esélyek, munkaerő-piaci stratégiák, In: Garai O. Horváth T. - Kiss L. - Szép L. - Veroszta Zs. (szerk.): Frissdiplomások 2010. Educatio Társadalmi Szolgáltató Nonprofit. Kft., Budapest, 37-58.

[12] P. Kiss (2013), Pályakezdók munkával való elégedettségének meghatározói, In: garai o. veroszta zs. (szerk.): Frissdiplomások 2011. Educatio Társadalmi Szolgáltató Nonprofit Kft. Felsőoktatási Osztály, Budapest, p. 265-291.

[13] E. Szűcs E., M. Fónai (2011), Measuring of Competencies of the University of Debrecen, In: Kalmár Ferenc - Balla Tibor (szerk.): XVII. Épületgépészeti, Gépészeti és Építőipari Szakmai Napok: szakkiállítás és Nemzetközi Tudományos Konferencia 2011. október 1314. [elektronikus dokumentum]. Debreceni Egyetem Múszaki Kar, Debrecen, 1-10.

[14] Sz. Nyüsti (2013), Frissdiplomás összevont adatbázis, Módszertani összefoglaló

[15] M. Fónai (2013), Az intézményi habitus eltérései és a karok státusza, In: Andl Helga Molnár-Kovács Zsófia (szerk.): Iskola a társadalmi térben és időben 2011-2012. II. kötet. Pécsi Tudományegyetem „Oktatás és társadalom” Neveléstudományi Doktori Iskola, Pécs. pp. 237-247., Kiss L.: „alacsony státuszú” szakok az alapképzésben. In: garai o. - veroszta zs. (szerk.): Frissdiplomások 2011. Educatio Társadalmi Szolgáltató Nonprofit Kft. Felsőoktatási Osztály, Budapest, 67-91.

[16] A. Gáti (2010), Társadalmi háttér és mobilitás, In: Garai O. - Horváth T. - Kiss L. - Szép L. Veroszta Zs. (szerk.): Frissdiplomások 2010. Educatio Társadalmi Szolgáltató Nonprofit. Kft., Budapest, 155-175

[17] M. Fónai (2010), Hallgatók professzió-képének elemei, In: Kozma T. - Perjés I. (szerk): Új kutatások a neveléstudományokban. Többnyelvűség és multikulturalitás. Aula Kiadó, Budapest, 227-246.

[18] M. Fónai (2010), A jogi és igazgatási képzési területen végzettek elhelyezkedésének presztízs szempontjai, In: 2010, 227-244. polyácskó o.: Felsőoktatásból a munkaerőpiacra. In: Fábri I. - Horváth T. - Nyerges A. (szerk.): Diplomás pályakövetés II. Elhelyezkedés, alumni, jó gyakorlatok. Educatio Társadalmi Szolgáltató Nonprofit Kft. 27-36.

[19] M. Sági (2011), Pályakezdő diplomások munkába állási stratégiái, In: 2011-es DPR, 111141.

[20] Diplomás 2010 DPR adatbázis

[21] Frissdiplomás 2011-2012, DPR adatbázis 